\title{
„PRZEZ DUCHA WIECZNEGO“ (Hbr 9, I4) Próba uściślenia sensu pneumatologicznego tego zwrotu
}

List do Hebrajczyków - na pierwszy rzut oka - mówi bardzo niewiele o Duchu Swiętym. Na dwanaście miejsc, w których zachodzi w tym liście termin pneuma, tylko w sześciu mowa jest bez wątpienia o Duchu Swiętym $(2,4 ; 3,7 ; 6,4 ; 9,8 ; 10,15.29)$. W tych zaś sześciu występuje trzykrotnie formuła wprowadzająca tylko cytat biblijny o typie: ,mówi Duch Swięty". Pozostałe trzy miejsca stwierdzają istnienie darów łaski w duszach wiernych dzięki Duchowi Swiętemu $(2,4 ; 6,4 ; 10,29)$. Z nich dwa $(2,4 ; 10,29)$ zdają się suponować osobowość Ducha Swiętego, stanowiąc paralele do wypowiedzi Pawłowych o Duchu, „który udziela każdemu tak, jak chce" (1 Kor 12,11) oraz o tym, jak wierni mogą Go „zasmucić” (Ef 4, 30). Obydwa te miejsca nie wykraczają treścią ${ }^{1}$ poza wspólną dla Nowego Testamentu naukę o eonie eschatologicznym szerzej pojętym i o znamiennym dla niego działaniu Ducha Świętego.

W powyższej statystyce celowo pominięto zwrot podany w tytule artykułu, zwrot do dziś dnia kontrowersyjny. Ma on następujący kontekst bliższy: „Jeśli bowiem krew kozłów i cielców oraz popiół z krowy, którymi skrapia się zanieczyszczonych, sprawiają oczyszczenie ciała, to o ile bardziej krew Chrystusa, który przez Ducha wiecznego złożył Bogu samego siebie jako nieskalaną ofiarę, oczyści wasze sumienia z martwych uczynków, abyście mogli służyć Bogu żywemu" (Hbr 9, 13n). Przedmiotem dyskusji pozostaje to, czy zwrot dià pneúmatos aiōníou

1 Ostatnio szereg autorów w Hbr 10, 29 „Krew Przymierza” odnosi do liturgii eucharystycznej. Por. J. Betz, Die Eucharistie in der Zeit der griechischen Väter. Band I, 1: Die Realpräsenz des Leibes und Blutes Jesu in Abendmahl nach dem NT, Freiburg - Basel - Wien 1961, 155 n. Stąd już łatwo utożsamić równoległy zwrot kontekstu "Duch laski” z tym znaczeniem eucharystycznym. Ciekawe wnioski na ten temat, który jednak wykracza poza ramy niniejszego artykułu, por. w pracy J. Lebeau, Le vin nouveau du Royaume, Paris - Bruges 1966, 119.164.166. 
można w ogóle odnieść do Ducha Świętego, a jeśli tak, w jakim sensie należy rozumieć wyrażoną tutaj narzędziowość Ducha w ofierze Chrystusa. Zanim podamy dotychczasowe wyniki badań nad sensem zwrotu, umieśćmy $\mathrm{w}$ tej całości kontekstualnej, jaką wykryła subtelna analiza struktury tego listu.

\section{Dane analizy struktury listu ${ }^{2}$}

Zwrot omawiany zachodzi w zwartej całości utworzonej przez 9, 11-14. Reprodukujemy ją po polsku z zachowaniem podziału na stychy ${ }^{3}$ :

9, 11 Ale Chrystus zjawiwszy się jako kapłan dóbr przyszłych przez wyższy i doskonalszy przybytek, nie ręką uczyniony - to jest nie na tym świecie,

9, 12 ani nie przez kozłów i cielców, lecz przez własną krew, wszedł raz na zawsze do Miejsca Świętego, zdobywszy wieczne odkupienie.

9, 13 Jeśli bowiem krew kozłów i cielców oraz popiół z krowy, którymi skrapia się zanieczyszczonych, sprawiają oczyszczenie ciała,

9, 14 to o ileż bardziej krew Chrystusa, który przez Ducha wiecznego złożył Bogu samego siebie jako nieskalaną ofiarę oczyści wasze sumienia $\mathrm{z}$ martwych uczynków, abyście służyć mogli Bogu żywemu.

W tym czterowierszowym urywku zachodzi współśrodkowa symetria pierwszych dwóch wierszy $(11-12)$ oraz równoległa symetria dwóch pozostałych (13-14). Ograniczmy się do tych ostatnich, gdzie zachodzi nasz zwrot. Równoległość pojęć rzuca się w oczy:

$$
9,13
$$

krew kozłów i cielców

skrapia się zanieczyszczonych oczyszczenie ciała

$$
9,14
$$

krew Chrystusa jako nieskalaną ofiarę oczyści sumienia

Jest to równoległość przeciwstawna zachodząca między niedoskonałym typem ze Starego Testamentu a doskonałym jego antytypem - w Nowym. Wprawdzie nasz zwrot nie występuje w powyższej antytezie, ale

2 Por. A. Vanhoye, La structure littéraire de l'Épître aux Hébreux (Studia Neotestamentica - Studia I), Paris - Bruges 1963, $149 \mathrm{nn}$.

3 Jest to tekst przekładu Ks. S. Eacha z II wydania Biblii Tysiąclecia: Pismo Swięte Nowego Testamentu w przekładzie z języka greckiego, Poznań - Warszawa 1969. Przedstawiono tylko tu nieznacznie szyk słów celem odtworzenia podziału stychicznego podanego przez A. Vanhoye. 
jest ona ważna, gdyż nadaje ton całej argumentacji. $\mathrm{Na}$ tej podstawie nasz zwrot, który jest jakimś - ogólnie mówiąc - okolicznikiem sposobu, winien wykazać bezwzględną doskonałość opisanego ofiarowania się Chrystusa.

Natomiast w innej antytezie, którą już przedtem wykryto ${ }^{4}$, zwrot omawiany wystąpi jako wyraźny kontrast. Mianowicie wyżej podany czterowiersz $(9,11-14)$ zawiera szereg pojęć przeciwstawnych do zawartych w poprzedzających dziesięciu wierszach. Oto ich zestaw:

skènè Starego Przymierza (9, 2-5) - doskonalsza skènè - ciało Chrystusa $(9,11)$

ciągłe wchodzenie kapłanów $(9,6)$ - jednorazowe wejście Chrystusa $(9,11 \mathrm{n})$

krew żertw $(9,7)$

- własna krew Chrystusa (9, 12)

żertwy się składa $(9,9)$

- Chrystus samego siebie złożył jako ofiarę $(9,14)$

przepisy tyczące się ci ała $(9,10)$ - Chrystus ofiarował siebie przez Ducha wi ecznego $(9,14)$.

Ostatnia para kontrastów pojęciowych zawęża nam kierunek poszukiwań sensu omawianego zwrotu. Ten okolicznik sposobu, w jaki Chrystus złożył samego siebie w ofierze, musi według intencji autora Listu do Hebrajczyków spełniać dwa warunki: 1) nie tylko uzasadniać ostateczną, bezwzględną wartość ofiary Chrystusa, co wynika z bezpośredniego kontekstu, 2) ale nadto opierać się w tym uzasadnieniu na biblijnym kontraście pneuma - sarx ${ }^{5}$. Ten drugi warunek odda nam cenne u.sługi w ocenie dotychczasowych prób rozwiązania naszego problemu. Pozwoli on bowiem na wyeliminowanie $\mathrm{z}$ góry tych interpretacji, które nie licząc się z owym biblijnym przeciwstawieniem pojęć, bazują na samoistnych znaczeniach terminu pneuma. A te pochodzą przeważnie ze skarbca pojęć greckich, zwłaszcza platońskich.

\section{Aktualne dziś typy rozwiązania problemu}

Trudny zwrot „przez Ducha wiecznego" miał wiele różnych interpretacji w dziejach egzegezy. Spośród nich za aktualne można uważać następujące typy, między którymi wiele komentarzy nie dokonuje rozstrzygającego wyboru. Przy tym jedni z autorów otwarcie rezygnują z zajęcia

4 Por. C. Spicq, L'Épître aux Hébreux (Études bibliques), Paris 1953, 2, 247.

5 Ten sam postulat metodologiczny, lecz na zasadzie innych paralel, wysuwa E. Schweizer, ThWNT 6, 445. 
zdecydowanego stanowiska między rozbieżnościami ${ }^{6}$, inni zaś bądź pomijają zagadnienie bądź posługują się ogólnikowymi określeniami, z pewnością poprawnymi, lecz nieadekwatnymi. Nie uzasadniają bowiem one faktu wyboru tego terminu przez autora listu ${ }^{7}$.

Niżej podana próba klasyfikacji ma za zadanie ułatwić czytelnikowi orientację $\mathrm{w}$ istnym lesie rozwiązań przez wyodrębnienie poszczególnych kierunków, obranych przez komentatorów. Rozgraniczenia te nie są też ostro zarysowane ani ekskluzywne - możliwe są między nimi formy pośrednie.

1. Rozwiązanie psychologiczno-moralne: „duch” oznacza d u s zę ludzką Chrystusa ${ }^{8}$ lub odwieczną Jego dyspozycję duchową ${ }^{9}$. Rozwiązanie to jest wprawdzie poprawne $z$ punktu widzenia filologicznego, gdyz Nowy Testament zna takie znaczenie psychologiczno-moralne terminu ,duch", orzekanego o ludziach ${ }^{10}$, a także o Jezusie ${ }^{11}$. Natomiast List do Hebrajczyków posługując się tym terminem na oznaczenie w ogóle ludzkiego ducha nie stosuje go do Jezusa, gdyż w 4,12 mamy trychotomiczny podział chrześcijanina (podobnie jak w 1 Tes 5, 23), a w 12, 9. 23 sama liczba mnoga rzeczownika nie pozwala nim objąć Syna Bożego. Głównym jednak kontrargumentem przeciw rozwiązaniu psychologiczno-moralnemu jest jego nieliczenie się z zamierzonym przez autora $\mathrm{w}$ tym kontekście przeciwstawieniem biblijnym pojęc pneuma - sarx. Stąd w najnowszych komentarzach już się nie spotyka tego rozwiązania.

2. Rozwiązanie pneumatologiczne: „Duch wieczny” to Duch Swięty, co już usiłowali wprowadzić do tekstu starożytni kopiści rękopisów ${ }^{12}$.

6 Por. A. Médebielle, w La Sainte Bible (Pirot-Clamer), Paris 1952, ad loc.; Teodorico da Castel S. Pietro, L'Epistola agli Ebrei (La Sacra Bibbia - S. Garofalo), Torino - Roma 1952, ad loc.; O. Kuss, Der Brief an die Hebräer und die Katholische Briefe (RNT - 8), Regensburg 1953, ad loc.

7 Por. W. Hillmann, Der Brief an die Hebräer (Die Welt der Bibel - 4), Düsseldorf 1965, ad loc.; F. J. Schierse, Der Brief an die Hebräer (Geistl. Schriftlesung - 18), Leipzig 1967, ad loc. ad loc.

${ }_{8}$ Por. P. Boylan, The Epistle to the Hebrews (WVSC - 4), London 1931,

9 Tak J. Bonsirven, Saint Paul. Êpître aux Hébreux (Verbum Salutis), Paris 1943, ad loc.; ten sam autor później zmienił zdanie, o czym niżej. Sposób ofiarowania się akcentuje O. Michel, Der Brief an die Hebräer, Göttingen 1949, $205 \mathrm{n}$.

10 Por. np. Mt 5, 3; 26, 41 par.; Ek 1, 47; Dz 17, 16; 19, 21; 1 Kor 2, 11; 2 Kor 2, $13 ; 4,13 ; \mathrm{Jk} 2,26 ; 1 \mathrm{P} 3,4$.

11 Por. Mk 2, 8; 8, 12; J 11, 33; 13, 21. Natomiast ,duch" w 1 P 3, 18, o czym szczegółowo niżej, nie mieści się, naszym zdaniem, w kategorii psychologiczno-moralnej.

12 Już tradycja rękopiśmienna wykazuje $\mathrm{w}$ tym miejscu wariant dia pneumatos agiou, poświadczony przez wielu świadków. Ocenia go się w krytyce jako poprawkę pierwotnego aiōniou (lectio difficilior). Szczegóły por. C. Spicq, L'Épître aux Hébreux, dz. cyt., 1, 424. 
Ten tradycyjny pogląd, znany od czasów patrystyki ${ }^{13}$ można następująco ująć słowami św. Tomasza z Akwinu: „,cuius motu et instinctu, scilicet charitate Dei et proximi, hoc fecit" ${ }^{14}$. Dzisiejsi reprezentanci tego zapatrywania ${ }^{15}$ opierają się na tym, że zwrot omawiany jest w zdaniu okolicznikiem sposobu, uzasadniającym wiekuistą doskonałość ofiary. Pochodzi ona stąd, że Duch Święty działa na Chrystusa jako kapłana własnej żertwy. Ujmując najogólniej: Chrystus-Arcykapłan jest w swojej ofierze krzyżowej ożywiony i napełniony Duchem ${ }^{16}$. U niektórych zwolenników tego rozwiązania można zauważyć wyraźne powiązania $\mathrm{z}$ pierwszym stanowiskiem $\mathrm{w}$ jego wersji moralnej ${ }^{17}$. Niewątpliwą zaletą tego rozwiązania jego to, że trzyma się ono najbardziej naturalnego znaczenia zestawu „Duch wieczny”. Skręt jednak w stronę psychologiczno-moralną podważa jego wartość. Taka bowiem teza opuszcza postulowaną przez kontekst bliższy płaszczyznę przeciwstawienia biblijnego „ducha” i „ciała”. Dla rozwiązania więc pneumatologicznego w dotychczasowej, wyizolowanej postaci brak jest dostatecznego uzasadnienia, choć intuicyjnie może się wydawać ono najlepszym. Do niego też wrócimy na końcu proponując pewną jego modyfikację.

3. Rozwiązanie chrystologiczne: omawiany zwrot charakteryzuje jakoś samego Chrystusa uzasadniając, dlaczego Jego ofiara jest doskonała i ostateczna. W ramach tego najliczniej dziś reprezentowanego stanowiska dadzą się wyróżnić dwa odcienie uzasadnienia.

a) Wartość definitywna ofiary Chrystusa ma za uzasadnienie wiekuistą naturę Syna Bożego. Niektórzy zwolennicy tego odcienia wytłumaczenia - zapewne powodowani lapidarnością zwrotu i brakiem bliskich paralel - ograniczają się do określeń ogólniko-

13 Tak sądzili w starożytności: Chryzostom i 'Teodoret, w średniowieczu: Tomasz z Akwinu, w czasach nowożytnych: Estius i Bengel, w wieku XIX: F. Bleek, W. M. L. De Wette.

14 Super Epistola S. Pauli (éd. Cai, 1953) cyt. za L. Sabourin, Rédemption sacrificielle, (Bruges) 1961, 318.

${ }_{15}$ Jak np. I. Rohr, Der Hebräerbrief und die Geheime Offenbarug des hl. Johannes (HSNT - 10), Bonn ${ }^{4} 1932$, ad loc.; W. Leonard, w: A Catholic Commentary on Holy Scripture, London .... 1953, ad loc.; H. Simón - J. Prado, Praelectiones biblicae, Taurini ${ }^{8} 1957, \mathrm{NT}, 2,410$.

${ }^{16}$ "Getrieben und erfüllt von Gottes ureigener Liebe" - streszcza to stanowisko G. Schiwy, Weg ins Neue Testament, Würzburg 1970, 4, 116.

17 Por. L. Sabourin, Rédemption sacrificielle, dz. cyt., 318. Autor ten właściwie usiłuje zsyntetyzować wszystkie trzy rozwiązania; A. Vanhoye, La structure..., dz. cyt., 248; Tenże, Situation du Christ (Lectio divina - 38), Paris 1969, 359. Między wypowiedziami tego autora zachodzi znamienna różnica: we wcześniejszej pracy mówi on o ,zupełnym posłuszeństwie wobec Ducha”, a w studium późniejszym rezygnuje z pisania terminu „esprit” dużą literą, a „ducha wiecznego” ocenia jako „impulsion”, co skłania Chrystusa do przyjęcia ludzkiego losu za swój. 
wych ${ }^{18}$. Inni zaś próbują go uzasadnić paralelami biblijnymi. I tak G. Ricciotti ${ }^{19}$ widzi paralelę w „duchu świętości” (Rz 1, 4). C. Spicq ponadto powołuje się na dwie paralele z tego samego Listu do Hebrajczyków - 7, 16. 24, nadto na 1 Tm 3, 16 oraz na cztery teksty patrystyczne. Niecodzienne zaś znaczenie ,Ducha” jako natury boskiej usiłuje wytłumaczyć określeniem duchowości Boga z J 4, 24, przeciwstawieniem do „ciała” zachodzącego w najbliższym kontekście oraz motywem psychologiczno-moralnym, mianowicie spontanicznością ofiary Chrystusa w przeciwieństwie do bezwolnych żertw zwierzęcych ${ }^{20}$. Ten odcień rozwiązania w ramach trzeciego stanowiska, najdojrzalej sformułowany przez C. Spicqa, nie zdobył jednak powszechnego uznania: już po nim ukazały się nowe próby. Uzasadnienia bowiem biblijnego, jak się niżej okaże, nie znajdzie się dla preegzystującej natury Syna, lecz jedynie dla stanu, w jakim złożył tę ofiarę, stanu określonego specyficznie biblijnym pojęciem, „Ducha”. Rozwiązanie, jakie dał C. Spicq, choć teologicznie najpoprawniejsze, jest - sit venia verbo - zbyt ,,chalcedońskie", by mogło interpretować wiernie myśl ucznia św. Pawła, zbyt oderwane od kategorii pojęciowych i słownictwa drugiej połowy I wieku.

b) Wartość definitywna ofiary Chrystusa płynie stąd, że złożył On ją Bogu należąc już do niebieskiej sfery ducha, w przeciwstawieniu do swego dawnego ziemskiego bytowania w ciele. Zwolennicy tego ujęcia uzasadniają swój pogląd paralelą do 7,16, gdzie wyższość Chrystusa nad Melchizedekiem opiera się właśnie na kontraście pneuma - sarx: ,(Chrystus) stał się (kapłanem) nie według prawa cielesnego (sarkinès), lecz według siły niezniszczalnego życia (zōes akatalýtou)" 21 W miejscach porównywanych występuje różnymi przymiotnikami wyrażone to samo przeciwieństwo, jakie zachodzi między ofiarą Chrystusa a ofiarami kapłanów Starego Przymierza. Stąd, zdaniem zwolenników tej interpretacji, można postawić znak równości między pojęciami ,niezniszczalnego życia” a ,ducha wiecznego". Wielką zaletą tego tłumaczenia jest

18 „Le Fils de Dieu, possédant par nature l'éternité, marquait de ce trait tous ses gestes": J. Bonsirven, Théologie du Nouveau Testament (Théologie - 22), Paris 1951, $402 \mathrm{n}$; ,belonging to the divine order': V. Taylor, The Person of Christ in NT Teaching, London - Melbourne - Toronto ${ }^{4} 1966,96$; "Chrystus bez grzechu, będący samą świętością...": S. Each, List do Hebrajczyków, (Pismo św. NT 10), Poznań 1959, 220.

19 Por. Lettere di San Paolo, Roma 21949, 549. 263.

20 Por. L,Epitre aux Hébreux, dz. cyt., $258 \mathrm{n}$.

21 Por. H. Montefiore, A Commentary on the Epistle to the Hebrews (BNTC) London 1964, ad loc.; M. M. Bourke, w: The Jerome Biblical Commentary, Englewood Cliffs 1968, 2, $397 \mathrm{n}$. 
lepsze wyzyskanie biblijnej dialektyki pneuma - sarx oraz właściwej dla tego listu nauki o dwóch fazach kapłaństwa Chrystusa ziemskiej i niebieskiej zainaugurowanej przez wniebowstąpienie ${ }^{22}$. Podana paralela z 7, 16 choć $\mathrm{w}$ sensie wyrazowym zdaje się nie oznaczać dokładnie tego samego, z pewnością trafnie bazuje na wspólnym dla obu porównywanych sytuacji fakcie wstąpienia Chrystusa do chwały. Przymiotnik bowiem aiōnios, jak już dawniej zauważono ${ }^{23} \mathrm{w}$ tym liście nie oznaczając „odwiecznego" ma zawsze sens eschatologiczny - czegoś, co mając początek, nie ma końca $(5,9 ; 6,2 ; 9,12.14 \mathrm{n} ; 13,20)$. Brakiem jednak tej interpretacji jest jej zdecydowane odcięcie się od sensu pneumatologicznego. Tymczasem, naszym zdaniem, ten sens nie tylko tu się zawiera z racji użycia samego terminu "duch", ale doskonale harmonizuje - jak wykażą paralele - z interpretacją chrystologiczną, gdyż od chwalebnego Chrystusa w teologii Nowego Testamentu nierozdzielny jest Spiritus Consummator.

\section{Proponowane rozwiązanie ${ }^{24}$}

Jest nim szczególny sens pneumatologiczny, nie wyizolowany, nie psychologizujący, lecz soteriologiczny. Wynika on z faktu uwielbienia Chrystusa mocą Ducha Świętego. Fakt ten jest daną niewątpliwą listów św. Pawła i pism Nowego Testamentu zależnych od myśli Apostoła Narodów. Uzasadnienie proponowanego rozwiązania oprze się na egzegezie omawianego zwrotu na tle kontekstu najbliższego i na tle kontekstu ideowego całego listu, zwłaszcza - jego doktryny o kapłaństwie niebieskim Chrystusa oraz uwzględni paralele nowotestamentalne, przytaczane $\mathrm{w}$ dotychczasowych próbach rozwiązania tego zagadnienia.

Zacznijmy od orzeczenia zdania, w którym nasz zwrot występuje jako okolicznik sposobu. Jest nim aoryst czasownika prosférein, który w języku Septuaginty należy do terminów technicznych z zakresu posługi ofiarniczej kapłanów. Za przedmiot bliższy ma ów czasownik ,samego siebie", co uwydatnia dobrowolność i ogrom miłości zawarty w tym geście kapłańskim Chrystusa. Znamienne jest przy tym pominięcie tutaj używanego gdzie indziej $\mathrm{w}$ tym liście terminu technicznego thysía (9, 23.

22 Por. A. Cody, Heavenly Sanctuary and Liturgy in the Epistle to the Hebrews, (St. Meinrad) 1960, 91.

23 Por. O. Kuss, kom. cyt., ad loc.

24 Nie została tu wykorzystana niestety jako w praktyce niedostępna praca J. J. McGrath, "Through the Eternal Spirit". An Historical Study of the Exegesis on Hebrews 9, 13-14 (Excerpta ex Dissertatione ad Lauream in Facultate Theologica PUG), Roma 1961. Na podstawie sprawozdania, jakie o niej dał L. Sabourin, Sacrificium ut liturgia in Epistola ad Hebraeos, VD, 46 (1968) 243 n (ods. 2), można stwierdzić zasadniczą zgodność jego rozwiązania z niżej podanym. 
$26 ; 10,12)$, w którym na plan pierwszy wybija się moment krwawej immolacji. Pominięcie to sugeruje, że autor w omawianym zdaniu ma na myśli nie tyle krwawy zgon na krzyżu, ile raczej $\mathrm{z}$ a of i a r o w a n i e siebie (oblatio) ${ }^{25} \mathrm{~W}$ taki sposób, który zapewnia złożonej ofierze nie tylko to, że jest „nieskalaną”, ale i wiecznie trwałą w skutkach ${ }^{26}$.

Zostawiając na razie na boku sam termin pneuma, zwróćmy uwagę na określający go przymiotnik aiōnios, który skłaniał wielu komentatorów do ujęć zbyt filozoficznych. Tymczasem, jak już wspomniano wyżej, autor listu używa go zawsze $w$ specyficznym eschatologiczn y $\mathrm{m}^{27}$ znaczeniu. I tak określa nim:

5, 9 zbawienie wiernych,

6, 2 wyrok sądu ostatecznego,

9, 12 zbawienie jako dzieło Chrystusa,

9, 15 dziedzictwo zbawionych,

13, 20 nowe przymierze.

Mówiąc więc obrazowo, przymiotnik ,wieczny" w liście tym patrzy tylko „,naprzód” ku wieczności, która czeka wiernych, nie zaś „wstecz” ku odwieczności Boga. Zatem w naszym zwrocie przymiotnikiem tym nie oznacza autor odwieczności preegzystującego Syna Bożego, choć w nią wierzy, lecz charakteryzuje Ducha jako sprawcę nie kończącej się nigdy wartości ofiary Chrystusa.

Ten sam wynik uzyskujemy zestawiając miejsca, w których - poza cytatami Starego Testamentu - autor mówi o Chrystusie posługując się okolicznikiem wyraźnie ,patrzącym wprzód”, jakim jest zwrot eis aiōnas. Oto ich sens teologiczny:

6, 20 Chrystus kapłanem na wieki dopiero od chwili wejścia do nieba

7, 24 trwanie na wieki zapewnia trwałość kapłaństwu (analogicznie do $7,16)$, o czym niżej

7, 28 Syn w kapłaństwie doskonały $\mathrm{n}$ a wieki, nie od wieków

13, 8 Chrystus trwa ,na wieki” w przeciwieństwie do Jego „wczoraj” i ,dziś”.

Z wymienionych wyżej miejsc 7, 24. 28 mogłyby na pierwszy rzut oka odnosić się równie dobrze do preegzystencji Syna Bożego 28. Pamiętać jednak trzeba, że cała argumentacja rozdziału 7-go stanowi swoistą relecture Ps 110(109), 4 i bazuje na „przysiędze”, która ustanawia Chrystusa

\footnotetext{
25 Por. J. Bonsirven, Théologie du NT, dz. cyt., 408.

26 Zob. ods. 9: O. Michel.

27 Por. O. Kuss, kom. cyt., ad loc.

28 Tak to uzasadnia C. Spicq, kom. cyt., 2, 197. 203.
} 
kapłanem $(7,16.24 .28)$. Tymczasem to ustanowienie nie jest odwieczne ${ }^{29}$, lecz wiąże się z życiem ziemskim Syna Bożego, co widać choćby z użycia aorystu, ilekroć jest mowa o rozpoczęciu przez Chrystusa posłannictwa kapłańskiego $(2,17 ; 5,5 ; 6,20 ; 9,11)$.

Dlaczego jednak $\mathrm{z}$ tych dwóch teoretycznych możliwości ${ }^{30}$ uzasadnieria ,życia niezniszczalnego" w 7, 16 wybieramy fakt zmartwychwstania Chrystusa, a nie to, co późniejsza teologia nazwie precyzyjnie unią hipostatyczną? Wybór nasz podyktowany jest postulatem metodologicznym trzymania się kategorii myślowych właściwych hagiografowi. Otóż dwie niewątpliwe dane zawarte $w$ liście skłaniają ku takiemu rozwiązaniu: występujący $\mathrm{w}$ bliższym kontekście naszego zwrotu szczególny wypadek kontrastu biblijnego ,duch” — „ciało” oraz właściwa autorowi listu koncepcja dwóch stadiów działalności kapłańskiej Chrystusa - na ziemi i sanktuarium nieba. Omówimy kolejno obie te dane.

W bliższym kontekście rozdziału 7-go kontrast sarx - pneuma ma rolę szczególną. Autor przeciwstawia sobie wzajemnie wielość ciągle powtarzanych $\mathrm{w}$ doczesności aktów ofiarniczych ze strony kapłanów Starego Przymierza i jedną jedyną eschatologicznie trwałą ofiarę Chrystusa. Kiedy i dlaczego ta ofiara Chrystusa krwawa, dokonana przecież też w doczesności, nabrała trwałego waloru eschatologicznego? Gdyby autor uznawał tylko jedno stadium kapłaństwa Chrystusa, odpowiedź mogłaby być tylko jedna: dzieje się tak, ponieważ dzięki preegzystencji boskiej kapłan jest wiekuisty. Istotnie, autor kładzie nacisk na bezwzględnie jednorazową ofiarę z życia, jaką złożył Jezus na krzyżu $(7,27 ; 9,12 ; 10,10.18)$. Ale nie w tym akcie upatruje szczytowe osiągnięcie Chrystusowego kapłaństwa. Dla autora Listu do Hebrajczyków - na zasadzie wartości soteriologicznej zmartwychwstania - wejście Chrystusa do chwały jest inauguracją drugiego, donioślejszego niż pierwsze, stadium kapłaństwa - liturgii niebieskiej ${ }^{31}$. „Wywyższony ponad niebiosa” $(7,26)$ znamienny zwrot, w którym aoryst dobitnie ukazuje moment czasowy rozpoczęcia tego stadium, wchodzi w skład swoistej definicji arcykapłana Chrystusa. Jeszcze wyraźniej to samo wypowiada autor we własnym streszczeniu wywodów, gdzie termin „liturg” określa dopiero Chrystusa,

${ }^{29}$ Jak sądzili spośród Ojców Kościoła: Euzebiusz z Cezarei i Cyryl Jerozolimski; spośród zaś nowożytnych teologów, w w. XVII - L. Thomassin. W w. XX reprezuntują to stanowisko teologowie protestanccy: F. Büchsel, J. Moffatt, E. Käsemann.

${ }_{30} \mathrm{~W}$ znamiennym porządku: „Belief in the eternal life of Jesus rests upon belief in the resurrection and in the divinity of Jesus" podaje te racje J. Smith, The Priest for Ever. A Study of Typology and Eschatology in Hebrews, London Sydney 1968, 85. Autor ten przyjmuje sens pneumatologiczny Hbr 9, 14: s. 6, 85, 142,160 .

31 Zauważyli to już $w$ dobie patrystycznej: Tertulian, Atanazy, Cyryl Aleksandryjski i Teodor z Mopswestii. 
„który zasiadł po prawicy tronu Majestatu” (8, 1n). Podobnie aorystem „,zasiadł" (ekáthisen) posługuje się autor, ciągle nawiązując do PS 110 (109), 4, w kontekstach mówiących o doskonałości kapłaństwa Chrystusa $(10,12 ; 12,2)$. Tak więc śmierć krzyżowa jest złożeniem ofiary z samego siebie, ale wejście do sanktuarium niebieskiego dopiero rozpoczyna chwalebną, wiekuistą fazę sprawowania najwyższego w Nowym Przymierzu kapłaństwa ${ }^{32}$. To samo o momencie wejścia do chwały da się stwierdzić, rozpatrując doskonałość ofiary od strony nie arcykapłana, lecz ż e r t w y. Obok bowiem akcentu spoczywającego na „własnej krwi” $(9,12)$ przelanej w fazie ziemskiej czytamy wzmiankę o ,doskonalszym przybytku" $(9,11)$. Jest nim ciało zmartwychwstałego Chrystusa, przedstawiona Bogu godna żertwa, całkowicie już przemieniona przez Ducha Bożego natura ludzka ${ }^{33}$. Taki Pośrednik może już w sposób doskonały wykonywać czynność nieprzemijającego wstawiennictwa kapłańskiego i ,,całkowicie zbawiać tych, którzy przez Niego zbliżają się do Boga" (7, 25).

Pozostaje $z$ kolei uzasadnić krótko wyżej wzmiankowany związek między chwalebnym wkroczeniem Chrystusa do wiekuistego sanktuarium a Duchem Swiętym, na którego wskazuje termin „Duch wieczny”, tzn. nadający wiekuistą wartość. Do tego celu posłuży nam szereg paralel z listów głównie Pawłowych, od których wyraźnie jest zależny autor Listu do Hebrajczyków w zakresie soteriologii.

\section{„Duch świętości” (Rz 1, 4) ${ }^{34}$}

Już adres, ściślej: praescriptum, Listu do Rzymian zawiera znamienny dla Pawłowej soteriologii tekst o Jezusie Chrystusie pochodzącym według ciała $\mathrm{z}$ rodu Dawida, a ustanowionym według $\mathrm{Duch}$ a świętości przez powstanie $z$ martwych pełnym mocy Synem Bożym (Rz 1, 3n). To starochrześcijańskie wyznanie wiary, jak się dziś przypuszcza ${ }^{3 \pi}$, obejmujące wiersze od 2 do 5 , jest nie tyle streszczeniem nauki o dwóch naturach w Chrystusie, ile raczej zarysem historii zbawienia. Ukazuje ono trzy stadia tej historii: Bożą zapowiedź o zbawieniu przekazaną za pośrednictwem proroków, pierwszy etap jej realizacji, jakim było życie

32 Por. J. Bonsirven, L'Êpître aux Hébreux, kom. cyt., 211 n; J. Dupont, „Filius meus es tu", RScRel, 35 (1948) 538 n; F.-X. Durrwell, La Résurrection de Jésus..., dz. cyt., 48. 167; D. M. Stanley, Christ's Resurrection in Pauline Soteriology (Analecta Biblica - 13), Roma 1961, 253.

33 Por. A. Vanhoye, „Par la tente plus grande et plus parfaite...”, Bib 46 (1965) 25.

34 Por. D. M. Stanley, Christ's Resurrection..., dz. cyt., 161-166; B. Schneider, Kata pneuma hagiosýnés (Romans 1, 4), Bib, 48 (1967), 359-387; R. Baulès L’Évangile puissance de Dieu (Lectio divina - 53), Paris 1968, 22-34. 33. $45 \mathrm{n}$.

${ }_{35}$ Por. O. Cullmann, Les premières confessions de foi chrétiennes, Paris 1948, 
doczesne Syna Bożego ,w ciele”, co tu jest synonimem zwrotu „w słabości" (2 Kor 13,4) i końcowy etap - dopełnienie posłannictwa w chwale zmartwychwstania. Etap drugi i trzeci zestawione ze sobą ukazują pouczający kontrast:

pochodzący z rodu Dawida - ustanowiony pełen mocy Syn Boży według ciała - według Ducha świętości przez powstanie z martwych.

Związek wewnętrzny - jakaś wzajemna implikacja - pojęć „moc”, „Duch świętości” i „,zmartwychwstanie” rzucają się tu w oczy. Podobnie wyraźny związek zachodzi między drugą grupą pojęć a „,ciałem” i „słabością", które charakteryzują doczesne życie Jezusa. Te same pokrewieństwa pojęć i te same kontrasty biblijne znajdujemy w Liście do Hebrajczyków, gdzie zwrot „według siły niezniszczalnego życia” $(7,16)$ odpowiada omawianemu zwrotowi ,przez Ducha wiecznego" $(9,14)$. Obydwa te zwroty, choć w różnych kontekstach mówią o tym samym - o wyższości niebieskiego kapłaństwa Chrystusowego nad ziemskie, aaronickie.

Nadto u Pawła można zauważyć na szeregu przykładów związek zachodzący między pojęciami pneuma a dýnamis. Podajemy je w porządku chronologicznym:

1 Tes 1, 5 - „przez moc i przez Ducha Świętego” głoszona

Ewangelia

1 Kor 2, 4 - „ukazywaniem ducha i mocy" jest kerygmat

Rz 15, 13. 19 - ,moc Ducha Świętego” towarzyszy wiernym

i apostołowi

2 Tm 1, 7 - ,nie dał nam Bóg ducha bojaźni, ale mocy”

Co jednak dokładnie znaczy rzadkie określenie „Duch świętości”? Jest to dosłowny przekład hebrajskiego $r u^{a} c h$ haqqodeš, które występuje u Iz 63, 10n; Ps 51 (50), 13, a wiąże się tam z obecnością w ludzie Bożym lub w poszczególnych ludziach stwórczej, ożywiającej mocy Bożej. Z tego zestawienia wynika, że „świętość” określająca „Ducha” tutaj jest synonimem boskości ${ }^{36}$. Komu ją przypisać? Paralelizm okoliczników katà sarka - katà pneuma sugeruje, że chodzi tu o jakąś cechę Chrystusa. Stąd dawniej u komentatorów ${ }^{37}$ przeważało utożsamianie ,,świętości" z bóstwem Syna, co było oczywiście jak najpoprawniejsze z punktu widzenia dogmatycznego. Ostatnio u komentatorów można zauważyć zwrot w stronę szukania kategorii myślenia właściwych Pawłowi. Do nich zaś niewątpliwie należy upatrywanie w Chrystusie „ostatniego Adama, który stał się duchem ożywiającym" (1 Kor 15, 45). Aoryst

36 Por. O. Procksch, ThWNT 1, 116.

37 Jak np. R. Cornely, F. Prat, M.-J., Lagrange, J. Huby, J. Bonsirven, A. Viard. 
egéneto wskazuje na pukt czasowy, w którym Chrystus stał się ,duchem ożywiającym". Tym zaś momentem, jak wynika z treści rozdziału, musiało być zmartwychwstanie. W tradycji stwierdził to już Ambrozjaster ${ }^{38}$. Przez zmartwychwstanie bowiem Duch Boży ${ }^{39}$ zawładnął ciałem Chrystusa do tego stopnia, iż ono samo z kolei staje się ",duchowym" (1 Kor $15,44)$, a przy użyciu skrótu myślowego - staje się po prostu ,Duchem" ${ }^{40}$. Co oczywiście nie oznacza bynajmniej tożsamości chwalebnego Chrystusa $z$ Duchem, lecz jedność dynamiczną działania na wiernych. Konsekwentnie więc „ducha świętości” z Rz 1, 4 rozumie się jako cechę Zmartwychwstałego: „transcendentne, dynamiczne źródło świętości w Jego stanie chwalebnym, na mocy którego ożywia On ludzkość" 41. Bliskie zaś sąsiedztwo „ducha świętości” z okolicznikiem ex anastáseos nekrōn - „przez ${ }^{42}$ powstanie z martwych” podkreśla zbawczą doniosłość zmartwychwstania Chrystusa ${ }^{43}$. Tego typu interpretacja jest trafna z dwóch względów. Po pierwsze liczy się ona $z$ podstawową prawdą kerygmatu apostolskiego o intronizacji Syna Bożego przez Jego wejście do chwały, wyrażoną w $\mathrm{Dz} 2,34-36 ; 13,32-29$, a powtórzoną potem w Hbr 1, 4n; 5, 5 44. Po drugie - pozwala na wydobycie typowo Pawłowego związku, jaki zachodzi między synostwem Bożym a Duchem Świętym. Szczególnym bowiem wypadkiem eschatologicznego wylania Ducha jest Boże synostwo wiernych będące udziałem w jedynej i niepowtarzalnej filiacji Syna Bożego, Jezusa Chrystusa. O tym mówią równoległe teksty Rz 8, 14-17; Ga 4, 4-7, gdy mowa o eonie obecnym, a Łk 20, 36, gdy chodzi o życie wieczne.

Stanąwszy na gruncie, że mowa tu o zbawczej doniosłości Chrystusowego zmartwychwstania, pozostaje odpowiedzieć, dlaczego Apostoł posłużył się w tym celu aż tak dziwnym hapax legomenon Nowego Testamentu ${ }^{45}$, jakim jest „duch świętości”. Dawny rabin pamiętał ten zwrot

38 In 1 Cor 15, 45: PL 17, 269.

39 Wyraźnie u Chryzostoma: „Duch Swięty”, In Epist. I ad Cor. hom., 41, 4: PG 61,359 .

${ }_{40}$ Por. L. Malevez, L'Église corps du Christ, RScR, 32 (1944) 50; F.-X. Durrwell, La Résurrection de Jésus..., dz. cyt., 122-128; N. Q. Hamilton, The Holy Spirit and Eschatology in Paul, Edinburgh - London 1957, 4-8; R. Koch, L'aspect eschatologique de l'Esprit du Seigneur, w: Studiorum Paulinorum Congressus Internationalis Catholicus (Analecta biblica - 17-18), Romae 1963, 1, 132 nn; B. Schneider, The Corporate Meaning and Background of 1 Cor 15, 45 $, \mathrm{CBQ}, 29$ (1967) 154.

41 J. A. Fitzmyer, The Letter to the Romans, w: The Jerome Biblical Commentary, dz. cyt., 2, 294.

42 Możliwe jest też czasowe ujęcie: „od (chwili) powstania z martwych".

43 Por. M.-E. Boismard, "Constitutus" Filius Dei (Rom 1; 4)" RB, 60 (1953) 5-17; D. M. Stanley, Christ's Resurrection..., dz. cyt., 165.

44 Por. G. Lohfink, Der historische Ansatz der Himmelfahrt Christi, „Catholica", 17 (1963) 46.

45 Ma go Test XII, Lewi 18, 11 - urywek, być może, interpolowany przez rękę chrześcijańską: por. M.-J. Lagrange, Saint Paul. Epître aux Romains, Paris 1950, 7. Występuje też $\mathrm{W}$ pismach z z Qumran: 1 Q S IV, 21; VIII, 16; IX. 3. 
z Biblii hebrajskiej. Jest on diametralnym przeciwstawieniem do „ciała grzechu" (sarx hamartías) z 8, $3^{46}$. Mimo wielkiej odległości od siebie oba te miejsca mówią o zbawczym planie Boga, o jego zwrotnym punkcie, jakim jest śmierć i zmartwychwstanie Chrystusa. Jeśli zaś się nie uzna tak odległego działania zależności pojęciowych, można znaleźć bliższe zamiar szczególnego podkreślenia świętości Bożej ${ }^{47}$. Nie ma potrzeby wykluczania sensu pneumatologicznego, zainicjowanego przez Chryzostoma, tylko na tej podstawie, że nie występuje tu termin techniczny pneuma hagion, co czynili dawniej komentatorzy. Ten sens postulowany przez sam termin pneuma wydaje się tu najwłaściwszy, najbardziej zrozumiały $\mathrm{u}$ dawnego rabina. Wystarczy zestawić ze Starego Testamentu takie teksty, jak np. Ez 37, 14;39, 29; Oz 6, 2; Ag 2, 5, by stwierdzić, że w świecie pojęć biblijnych ponowne ożywienie człowieka i umieszczenie go w Bożej obecności przypisuje się Duchowi Bożemu. Toteż zrozumiałe jest u św. Pawła stawianie obok siebie lub zamiennie pojęć: „zmartwychwstanie”, „duch” i „chwała” (Rz 6, 4; 8, 2. 10n; 1 Kor 15, 45; 2 Kor $3,17 n)$. Terminy te określają $z$ jednej strony to, co się dzieje z Chrystusem w tajemnicy paschalnej, z drugiej zaś to, co jest jej następstwem zbawczym dla nas: „nowe życie”, „wyzwolenie”, ,,jasność Pańska". Jeśli nadto uwzględnimy tu trzy metafory pneumatologiczne i zarazem eschatologiczne u Pawła 48: ,,pierwsze dary”, ,,zadatek" i ,pieczętowanie" (Rz 8, 23; 2 Kor 1, 22; 5, 5; Ef 1, 13n; 4, 30) - sens pneumatologiczny „Ducha świętości” zyskuje pęne prawdopodobieństwo, jeśli nie stanowi jedynego adekwatnego wytłumaczenia tego. zwrotu. Trzy składniki formuły wyznania wiary z Rz 1, 3n: „Duch świętości”, ,,w mocy" i ,przez powstanie z martwych" implikują się wzajemnie, gdyż wszystkie określają jedną i tę samą rzeczywistość chwalebnego Chrystusa, i to przy użyciu terminów występujących w Piśmie św. zamiennie: pneuma - doxa - dýnamis ${ }^{49}$. Różnicę aspektów można by tak oddać: podmiotem jest "Syn Boży", poziom Jego nowego życia oznacza zwrot ,,w mocy”, a zasadę ,,powstanie z martwych”, którego sprawcą jest „Duch świętości" 50. Nic nie wskazuje na to, by termin pneuma miał tutaj swoje rzadsze, wyłącznie antropologiczne znaczenie, którego zastosowania do Chrystusa nie da się udowodnić. Jest zatem biblijnym Duchem Bo-

46 Tak sugeruje R. Baulès, L'Évangile puissance de Dieu, dz. cyt., 34.

47 Tę propozycję wysuwa L. Legrand, L'arrière-plan néotestamentaire de Lc I, 35, RB, 70 (1963) 180, gdzie autor dostrzega wiele analogii między Łk 1, 35 a Rz $1,4 \mathrm{z}$ tą jednak różnicą, że każdy $\mathrm{z}$ tych hagiografów gdzie indziej $\mathrm{w}$ czasie umieszcza początek eonu eschatologcznego nadchodzącego z Chrystusem.

48 Por. artykuł mój Sens trzech przenośni Pawłowych..., w: „Sląskie Studia Historyczno-Teologiczne", 4 (1971) 23-37.

49 Por. np. w ST: Sdz 14, 6; Iz 11, 2; 48, 13; 63, $11 \mathrm{n} ; \mathrm{Mdr} 11,20$; w NT:

Rz 6,$4 ; 3,11 ; 15,13.19 ; 2$ Kor 13,$4 ;$ Ef $1,18 \mathrm{nn} ; 3,16$.

50 Por. R. Baulès, L'Évangile puissance de Dieu, dz. cyt., 28 n. 
żym - nazwanym przez Nowy Testament Duchem Swiętym, a przez późniejszą teologię - Trzecią Osobą Trójcy ${ }^{51}$. Użyty tu przyimek katà powtarzający się dwukrotnie przeciwstawia sobie dwie kolejno następujące po sobie plaszczyzny życia Jezusa Chrystusa jako Zbawcy. W płaszczyźnie drugiej - od chwili zmartwychwstania - Duch Swięty sprawia, że także dla nas Chrystus, jest „,pełnym mocy Synem Bożym”.

Jak widać zatem, termin „Duch świętości” z Rz 1, 4, należy do typowej dla Pawła pneumatologii, typowej, bo ściśle powiązanej z soteriologią i eschatologią.

\section{„Usprawiedliwiony został w Duchu” (1 Tm 3, 16)}

Drugi ten zwrot stanowiący pouczającą paralelę do omawianego zwrotu z Hbr 9, 14 występuje w hymnie chrystologicznym:

„A bez wątpienia wielka jest tajemnica pobożności:

Ten, który objawił się w ciele, usprawiedliwiony został $\mathrm{w} \mathrm{Duchu}$, ukazał się aniołom, ogłoszony został poganom, znalazł wiarę w świecie, wzięty został w chwale".

Jest to nie tyle hymn sławiący Człowieka-Boga w Jezusie ${ }^{52}$, ile raczej hymn liturgiczny, paschalny ${ }^{53}$. „Tajemnicą" — ściślej: żywym misterium - jest w nim Chrystus zmartwychwstały objawiający się na ziemi i w niebie. Trzy antytezy wydobywają na jaw powszechny zakres tego objawienia się w dwóch płaszczyznach:

$$
\begin{aligned}
& \text { NA ZIEMI } \\
& \text { „w ciele" } \\
& \text { „poganom" } \\
& \text { „na świecie" }
\end{aligned}
$$

$$
\begin{aligned}
& \text { W NIEBIE } \\
& \text {,w Duchu" } \\
& \text {,aniołom" } \\
& \text {,w chwale". }
\end{aligned}
$$

51 Por. tamże, 23. Znamienną niekonsekwencję pod tym względem wykazuje F.-X. Durrwell, La Résurrection..., dz. cyt. 122 ods. 48 stwierdzając najpierw: „Nous n'avons reconnu dans cet "esprit de sainteté» ni la nature divine, ni le Pneuma personnel; nous l'avons interprété de la sainteté divine qui marque l'homme Jésus et exige pour lui la résurrection en une existence conforme à cette sainteté, celle d'un authentique Fils de Dieu" - co bardzo jest trudno udowodnić tekstami a potem przyznając tamże związek z Duchem osobowym: „suscitée par l'Esprit”, tym razem z dużej litery.

52 Jak sądzi C. Spicq, Saint Paul. Les Épîtres pastorales (Études bibliques), Paris 1947, 108.

53 Por. A. Descamps, Les Justes et la Justice dans les évangiles et le christianisme primitif hormis la doctrine proprement paulinienne, Louvain - Gembloux 1950, 84-89; J. Dupont, Syn Christö(i). L'Union avec le Christ suivant saint Paul, Bruges - Louvain - Paris 1952, 1, $109 \mathrm{n}$. 
Prawa kolumna mówi w sposób oczywisty o Chrystusie paschalnym. W lewej - pozycja druga i trzecia streszczają kerygmat paschalny Kościoła, natomiast pierwsza - zdaje się nawiązywać do Wcielenia. Nie brakło nawet prób uzasadnienia związku pojęciowego w pierwszym sty$\mathrm{chu}$ przez zaakcentowanie negatywnej strony biblijnego terminu sarx: dlatego ,usprawiedliwiony”, ponieważ „ciało" wiąże się z grzechem, wprawdzie nie własnym, lecz przyjętym w imieniu grzesznej ludzkości ${ }^{54}$. Ta interpretacja pierwsza jest najzupełniej zgodna z soteriologią Pawłową. Niemniej można inaczej interpretować termin ,w ciele", mianowicie W sensie realności ciała zmartwychwstałego Chrystusa, jaką z naciskiem podkreśla znany apologetyczny urywek: „Dotknijcie się mnie i przekonajcie: duch nie ma ciała (sarka) ani kości, jak widzicie, że je mam" (Ek 24, 39). W drugiej interpretacji uzyskuje się dwa harmonizujące ze sobą szeregi kontrastów. A więc w stychach pierwszym i drugim, które nas głównie obchodzą, ukazują się dwa aspekty objawienia się Zmartwychwstałego: w realnym Jego ciele i w działaniu Ducha ${ }^{55}$. Nawet jednak bez przyjęcia drugiej interpretacji, która nam się wydaje słuszniejsza, walor analogii dla nas jest ten sam, jak stwierdzają sami zwolennicy pierwszej: ścisły związek zmartwychwstania, nie nazwanego wprawdzie wprost, ale suponowanego przez ,wzięcie do chwały”, i Ducha ${ }^{56}$.

$\mathrm{Na}$ ogói się przyjmuje, że termin „usprawiedliwiony” nie ma tutaj swego technicznego znaczenia $\mathrm{z}$ zakresu Pawłowej soteriologii, lecz stwierdza po prostu wykazanie słuuszności sprawy ${ }^{57}$. Greccy Ojcowie Kościoła idąc za pierwszą z interpretacji w ,ciele" upatrywali naturę ludzką, a „Duchu” zaś - boską Chrystusa. „Usprawiedliwienie” polegałoby więc na ujawnieniu, kim jest Jezus naprawdę. Od czasów jednak Kajetana łączy się ,usprawiedliwienie” z faktem zmartwychwstania, widząc tu analogię do $\mathrm{Rz} \mathrm{1,} \mathrm{4.} \mathrm{Za} \mathrm{sensem} \mathrm{pneumatologicznym,} \mathrm{nieodłącznym}$ od zmartwychwstania, przemawia jeszcze i to, że samo ,przekonanie świata o sprawiedliwości" Chrystusa jest zadaniem wyraźnie przypisanym Duchowi Parakletowi (J 16, 8. 10), jak zresztą i eschatologiczne „otoczenia chwałą" Chrystusa (J 16, 14). Świadom tego był Kościół pierwotny, skoro zbawcze skutki wywyższenia Chrystusa uważał za przedmiot wspólnego świadectwa apostołów i Ducha Świętego (Dz 5, 30nn) 58 .

54 Tak sugeruje F.-X. Durrwell, La Résurrection..., dz. cyt., 66 n.

55 A nie tylko,,w sferze duchowej”, jak chce E. Schweizer, ThWNT 6, 414. Niezależnie od podanej wyżej argumentacji za sensem wyraźnie pneumatologicznym przemawia tu bliższy kontekst - 5, 1, gdzie anaforycznie wprowadzone to pneuma oznacza na pewno Ducha Swiętego.

${ }_{56}, \ldots . . .11$ a été «justifié dans l'Esprit» par la Résurrection”. P. Benoit, Ascension, w: Exégèse et Théologie, Paris 1961, 1, 387 (poprzednio: RB, 56 (1948) 182). Por. G. Schrenk, ThWNT 2, 218.

${ }_{57}$ Por. Mt 11, 19; Łk 7, 35; 10, 29; Rz 3, 4.

58 Por. G. A. Denzer, The Pastoral Letters, w: The Jerome Biblical Commentary, dz. cyt., 2,355 . 
Biorąc jednak pod uwagę liturgiczne pochodzenie tego hymnu, można ściślej sprecyzować sens zwrotu ,usprawiedliwiony w Duchu”. Jeśli bowiem hymn ten jest paschalny, to tym samym jest soteriologiczny, gdyż nie tylko u Pawła, ale i przed nim, zbawczy charakter zmartwychwstania należy do pierwotnego Credo. Stąd działanie Ducha wyrażone terminem „usprawiedliwiony” winno być czymś więcej niż tylko obecnością Ducha w kerygmacie paschalnym Kościoła. W terminie tym można dostrzec moment ekspiacji zawartej $\mathrm{w}$ zmartwychwstaniu, o czym mówi przedpawłowa ${ }^{59}$ formuła $\mathrm{z} \mathrm{Rz} 4$, 25, i Pawłowe stwierdzenie z 1 Kor 15, 17. Skoro bowiem Chrystus ,,powstał z martwych dla naszego usprawiedliwienia”, ,a jeśli nie zmartwychwstał, aż dotąd pozostajemy w swoich grzechach" - zatem usprawiedliwienie nabiera tu sensu bliższego Pawłowemu, technicznemu, z tą jednak różnicą, że orzeka nie o skutku w poszczególnych wiernych, ale o przyczynie, jaką jest Chrystus zmartwychwstały. Dokonano niedawno ${ }^{60}$ odkrywczego zestawienia: lapidarne, a przez to trudne adagium Pawłowe: „Kto bowiem umarł, stał się wolny (dosłownie: ,usprawiedliwiony”: delikaíōtai) od grzechu” (Rz 6, 7) stanowi paralelę dla omawianego miejsca $1 \mathrm{Tm} 3,16$. To właśnie chwała zmartwychwstania sprawia, że zupełne należenie Jego ludzkiej natury do Boga, godne jest nazwy ,usprawiedliwienia”. Nie trzeba dodawać, że nie chodzi tu o żadną formę adopcjanizmu, lecz jedynie o autentyczną biblijną koncepcję zmartwychwstania zbawczego, w której udział Ducha Świętego wyraźnie się zaznacza, jak to wynika z zestawienia wielu tekstów dotąd cytowanych. Można więc zakonkludować: „Przez Ducha Swiętego zmartwychwstały Chrystus już zadośćuczynił za grzech, zwyciężył śmierć i szatana" 61. Tym samym zwrot ,usprawiedliwiony w Duchu" jeszcze bardziej przez swój moment ekspiacyjny zbliża się do omawianego zwrotu z Hbr 9, 14.

\section{„Powołany do życia Duchem” (1 P 3,18$)^{62}$}

Zwrot powyższy zachodzi również w hymnie liturgicznym, w którym można dostrzec - na podstawie lapidarnych sformułowań - zaczątki tworzącego się wyznania wiary w Chrystusa:

„Chrystus bowiem również raz umarł za grzechy, sprawiedliwy za niesprawiedliwych,

59 Por. A. M. Hunter, Paul and his Predecessors, London ${ }^{2}$ 1961, 24-35.

60 Por. C. Kearns, The Interpretation of Romans 6, 7, w: Studiorum Paulinorum..., dz. cyt., 1,305 .

${ }_{61}$ R. Koch, L'aspect eschatologique..., art. cyt., 134.

62 Por. U. Holzmeister, Commentarius in Epistulas SS. Petri et Iudae Apostolorum, Parisiis 1937, 1, 297-300; M.-E. Boismard, Quatre hymnes baptismales dans la I-e Epître de Pierre (Lectio divina - 30), Paris 1961, 57-109. 
aby was do Boga przyprowadzić, zabity wprawdzie na ciele, ale powołany do życia Duchem". Powyższy przekład ${ }^{63}$ już jest pewną interpretacją tego miejsca, nie jedyną zresztą. Budowa końcowych określeń chrystologicznych jest idealnie symetryczna: thanatōtheis men sarki - zōopoiētheis de pneúmati. Partykuły men i de formalnie uwydatniają zamierzony kontrast. Występuje on nie tylko $\mathrm{w}$ znaczeniu obu czasowników tu użytych $\mathrm{w}$ formie imiesłowów aorystu biernego, które dosłownie można oddać: „uśmiercony” — „ożywiony”, ale również i w okolicznikach. Tymi są przeciwstawne pojęcia biblijne sarx - pneuma.

Bezspornie przyjmuje się, że wyrażone są tu dwa zbawcze fakty: śmierć i zmartwychwstanie Chrystusa. Kontrowersyjne natomiast są oba okoliczniki wyrażone celownikami oraz sens terminu „duch”. Jaki to jest dativus? Padały $\mathrm{w}$ dziejach egzegezy dwie odpowiedzi: dativus relationis lub causae, ale to nie wpływało zasadniczo na sprecyzowanie sensu terminu „duch”. Zwolennicy jednej i drugiej odpowiedzi szli często za zdaniem greckich Ojców Kościoła i widzieli tu odróżnienie dwóch natur Chrystusa ${ }^{64}$. Ci, którzy dziś przyjmują tu dativus relationis formułują to przez kontrast: „w sferze cielesnej” — „w sferze duchowej”. Przy uznaniu jednak $\mathrm{w}$ tych okolicznikach swoistego dativus causae, mianowicie racji, dla której Chrystus umarł i zmartwychwstał, wówczas nie zachodzi potrzeba uciekania się w stronę nauki o dwóch naturach Chrystusa, gdyż biblijny kontrast „ciało” — „duch” pozostanie na płaszczyźnie dynamiki zbawczej. Parafrazując więc można to tak wyrazić ,poniósł śmierć zbawczą, ofiarowując swoje śmiertelne ciało, podobne do naszego grzesznego ciała, a przez zmartwychwstanie otrzymał ożywiającego nas Ducha”. To właśnie „Duch”, którego można biblijnie zdefiniować jako „darzącego życiem” ( $\mathrm{J}$ 6, 63), uzasadnia zbawcze ożywienie Chrystusa poprzednio pozbawionego życia. Nacisk spoczywa tu na „ożywieniu”, co odpowiada wspaniałej wizji Ezechiela w rozdz. 37. Jak tam, tak i tutaj Duch wskrzesza „wielkie wojsko". Tutaj zaczyna On od zwycięskiego wodza. Jest nim Chrystus - „pierwociny spośród tych, którzy pomarli” (1 Kor 15, 20). Zresztą ogniwem pośredniczącym między Chrystusem zmartwychwstałym a wiernymi jest i tutaj Duch Święty, jak to stwierdził św. Paweł: „Jeżeli mieszka w was Duch Tego, który Jezusa wskrzesił

63 Ks. F. Gryglewicza z Biblii Tysiąclecia, NT22.

64 Tak ostatnio jeszcze przyjmuje K. H. Schelkle, Die Petrusbriefe. Der Judasbrief (Herders Theol. Kommentar zum NT - XIII, 2) - Freiburg - Basel Wien 1964, 104, sprowadzając do tego samego sensu również $\mathrm{Rz} 1,3 \mathrm{n} ; 1 \mathrm{Tm} 3,16$. Słusznie spotkał go zarzut pomieszania pojęcia bóstwa $\mathrm{z}$ istnieniem niematerialnym: por. W. J. Dalton, Christ's Proclamation to the Spirits (Analecta biblica 23), Rome 1965, 133. 
z martwych, to Ten, co wskrzesił Chrystusa z martwych, przywróci do życia (zōopoiēsei) wasze śmiertelne ciała mocą mieszkającego $\mathrm{w}$ was swego Ducha" (Rz 8, 11).

Sens „Ducha” w 1 Tm 3, 18 można jeszcze nieco wycieniować. Jest to nie tylko Boża moc wskrzeszająca, na co wskazuje passivum theologicum, lecz zarazem - jak w poprzednich paralelach - nowa forma bytowania Chrystusa. W lapidarnej formie pneúmati na pierwszym miejscu trzeba widzieć raczej skutek, na drugim jego transcendentną przyczynę, to jest Ducha Świętego. Na taki porządek zdaje się wskazywać kontekst bezpośrednio następujący — zstąpienie Chrystusa do Otchłani. Nie wdając się tu w labirynt dyskusji na temat tego trudnego i wciąż kontrowersyjnego miejsca, wystarczy tylko stwierdzić: zwrot en hö(i) odnosi się do jakiejś mocy czy do stanu, w jakim Chrystus poszedł głosić zbawienie w Otchłani ${ }^{65}$.

„Ożywiony Duchem” charakteryzuje więc dopiero zmartwychwstalego Chrystusa, nawiązując nie do boskiej Jego preegzystencji, lecz do dynamiki zbawczej, jak to jest u św. Pawła, a także i u św. Jana np. w J $6,62 \mathrm{n} ; 7,39 ; 20,22 \mathrm{n}$.

\section{Wnioski końcowe}

Omówione wyżej paralele, w których konsekwentnie staraliśmy się wszędzie wydobyć sens soteriologiczny, wskazują bez wątpienia na to, że tworzące się Credo pierwotnego Kościoła zawierało już prawdę o zbawczej wartości zmartwychwstania Chrystusa. Jednocześnie wszystkie te teksty mówią o udziale Ducha Swiętego w misterium paschalnym. Te dane podsumowane skłaniają do tego, by zwrot ,przez Ducha wiecznego" z Hbr 9, 14 interpretować w ten sam sposób. Nowością Listu do Hebrajczyków jest tylko połączenie tych wspólnych wielu pismom Nowego Testamentu danych soteriologicznych $\mathrm{z}$ nauką o jedynym kapłaństwie Chrystusa, zwłaszcza z zupełnie oryginalną koncepcją autora - kapłańską teologią wniebowstąpienia. Pneumatologiczny sens zwrotu ,pprzez Ducha wiecznego" można dwojako interpretować. Odcień psychologiczno-moralny akcentuje tu impuls, jaki Duch Swięty nadaje Chrystusowi kapłanowi w spełnieniu Jego ofiary ${ }^{66}$. Ten odcień byłby zupełnie do przyjęcia w pismach Łukaszowych. Czy jednak w ten sposób myślał autor Listu do Hebrajczyków? Żadnych na to dowodów nie znajdziemy w skąpych zresztą tekstach tego listu wspominających Ducha Świętego. Dlatego ostrożniej będzie trzymać się tylko teologii wniebowstąpienia

65 Por. G. Schiwy, Weg ins NT, dz. cyt., 4, 210.

66 „Potentiam, quae Christum agit in suo sacrificio” sugeruje L. Sabourin, Sacrificium ut liturgia..., art. cyt., $243 \mathrm{n}$. 
właściwej dla tego listu: Chrystus Arcykapłan wchodzi do wiekuistego sanktuarium nieba, by tam Ojcu przedstawić złożoną raz na krzyżu ofiarę, wchodzi zaś w chwale i w „mocy życia niezniszczalnego”, zapewnionego Mu przez Ducha Swiętego. To ów Spiritus Consummator jest sprawcą tej pełni chwały w Chrystusie, która tu na ziemi jest łaską, rozdawaną przez tegoż Ducha $\mathrm{z}$ pełni Chrystusowej w sakramentach Kościoła ${ }^{67}$, zwłaszcza w Eucharystii ${ }^{68}$.

67 ,....après sa glorification par la Résurrection et le Retour auprès du Père, il (=le Christ) possédera dans son corps même la plénitude de l'Esprit, qu'il pourra dispenser par le moyen des sacrements", P. Benoit, L'Ascension, art. cyt., 1, 389.

68 „Dans la doctrine paulinienne, le corps du Christ fut divinisé (c'est-à-dire saisi par la vertu glorifiante de Dieu) dans l'Esprit-Saint de la résurrection", F.-X. Durrwell, La Résurrection..., dz. cyt., 375.

\title{
S U M M A R I U M
}

\author{
„PER SPIRITUM AETERNUM” (Hbr 9, 14) \\ SENSUS PNEUMATOLOGICUS HUIUS LOCUTIONIS ACCURATIUS \\ DEFINIRI TEMPTATUR
}

Quo melius investigandi iter eligatur, praemittuntur ea, quae de contextus proximi structura iam sunt stabilita (C. Spicq, A. Vanhoye), strictus videlicet parallelismus antitheticus versuum 9,13 et 14 (notiones: sanguis, puritas, emundatio) necnon quinque opposita in sectione 9, 11-14, inter quae oblatio ,per Spiritum aeternum" excellentior apparet ,iustitiis carnis” in Vetere Testamento. Exinde duo eruuntur interpretandi postulata: 1) locutio nostra explicet oportet, cur Christi sacrificium omnimode sit perfectum, 2) necesse est in explicanda heic voce PNEUMA prae oculis habere notissimam in S. Scriptura oppositionem cum notione SARX (BASAR), cuius oppositionis casus quidam particularis seligendus est, qui contextui sit consentaneus.

Deinde exponuntur recentiorum auctorum opiniones ad tria genera redactae: 1) solutio psychologico-moralis, secundum quam vox PNEUMA vel animam Christi humanam vel Ipsius propositum designat; 2) pneumatologica: „Spiritus aeternus" idem est ac Spiritus Sanctus (lectio Vulgatae): „cuius motu et instinctu, scilicet caritate Dei et proximi" (S. Thomas Aquinas) Christus semetipsum obtulit; 3) christologica - nunc frequentissima - quae vocem PNEUMA cum indole quadam Christi coniungit. Quae sit ista indoles, duplici modo respondetur: vel ontologice rem considerando - Christi divinitas vel soteriologice - status Christi gloriosus, quo pollens intrat Ipse sanctuarium caeleste. Tria haec genera solutionum non ita plene nos satisfaciunt. Nempe prima solutio eliminari potest, utpote quae oppositionem PNEUMA - SARX omnino neglegat. Secundae solutionis, quae iure meritoque proprium vocis PNEUMA significationem inculcat, forma nunc vigens saporem psychologico-moralem denuo induit, qui cum inculcata oppositione PNEUMA SARX vix potest componi. Si ergo debet retineri, alio modo exponatur oportet nexus Christi gloriosi cum Spiritu Sancto. Tertiae denique solutionis forma prima non satis attendit ad hagiographi notiones proprias, altera vero immerito praecludit 
nexum cum Spiritu, postulatum tum ab ipsa voce PNEUMA, tum a doctrina communi Novi Testamenti de Christi resurrectione.

Nobis igitur arridet solutio pneumatologica, sed a supra exposita parum distincta, videlicet soterio-pneumatologica. Quam quidem hoc modo adstruimus. Imprimis e contextu proximo epistolae eruitur sensus adiectivi ,aeternus", qui hoc loco est non ontologicus, sed biblicus, eschatologicus, uti patet ex: 5,$9 ; 6,2 ; 9,12.15 ; 13,20$. Idem confirmatur usu locutionis ,in saecula" hac in epistola $(6,20 ; 7,24.28 ; 13,8)$, nam semper agitur de aeternitate, quae fine carens habet profecto exordium in Christi glorificatione. Constat enim auctorem $\mathrm{Hbr}$ nosse duo sacerdotii Christi stadia: terrestre, tempore circumscriptum, quod crucis sacrificio cruento finitur, et caeleste, in quo eiusdem sacrificii fructus a Christo praesentatur Deo Patri in caelorum sanctuario. Glorificatio autem Christi manifesto iungitur nexu cum Spiritu Sancto. Quod quidem ex locis parallelis patet: $\operatorname{Rm~1,~3s;~} 1$ Tm 3, 16; 1 P 3, 18 .

In praescripto $\mathrm{Rm} 1$, 3s reperiuntur vestigia vetustissimae confessionis fidei, in qua non tam duae Christi naturae, quam duo operis redemptionis stadia exhibentur (B. Schneider, D. M. Stanley). Quam ob rem „spiritus sanctificationis” idem est ac Spiritus Dei, auctor indolis specialis Christi a mortuis resuscitati, dum e contra sensus anthropologicus vocis PNEUMA huic contextui minime esset consentaneus.

„Iustificatus autem Spiritu” (1 Tm 3, 16) dicitur Christus gloriosus in antiquo hymno, fortasse paschali, qui Eius manifestationem canit post resurrectionem demum factam. "Iustificatus" vero non quidem sensu - ut aiunt - technico Paulino, nam agitur de Redemptore, non de homine redempto, sed valde propinquo. Spiritu enim auctore fit, ut Christus gloriosus causa sit iustificationis ( $\mathrm{Rm} \mathrm{4,25).}$

Iterum in hymno, qui olim baptismalis fuisse censetur, Christus nuncupatur "vivificatus Spiritu" (1 P 3, 18) post mortem suam corporalem. PNEUMA heic est non solum Dei potentia, sed etiam quaedam Christi gloriosi indoles, consideranda una cum causa principali - Spiritu Sancto.

Hi tres textus paralleli prae primis, quid valeat Christi resurrectio in opere redemptionis clare ostendunt. Sed simul de speciali quadam participatione Spiritus Sancti in opere salvifico praecipue in mysterio paschali loquuntur. In Hbr 9, 14 adest igitur theologia Ascensionis Domini propria auctoris epistolae, sed nixa communi Novi Testamenti doctrinā de Spiritu Consummatore, qui et plenitudinis gloriae Christi est auctor, et efficaciae sacramentorum Ecclesiae, praecipue Eucharistiae. 